\title{
JUURNAL_RU
}

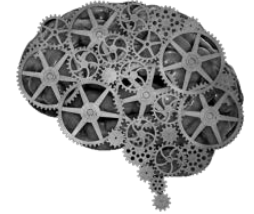

COMPANY GROUP "INTELLEKT"

\author{
Пешикова А.А. \\ Донской государственный технический университет \\ Ростов-на-Дону, Россия
}

doi: 10.18411/lj2016-3-72

\section{Роль образовательного консалтинга в повышении качества «знаниевых» ресурсов экономики страны.}

В XXI веке в России происходит повышение значимости сферы образования, которая выступает в качестве основного «строительного кирпичика» новой экономики страны. Роль образования в современной экономике со временем увеличивается одновременно с необходимостью всестороннего развития «знаниевых» ресурсов страны. В качестве отличительных особенностей «знаниевой» экономики можно выделить $[1, \mathrm{C}$. 165-166]:

1. превращение интеллектуальных ресурсов в ведущие ресурсы развития «новой экономики России»;

2. «информатизация» практически всех видов экономической деятельности организаций;

3. увеличение скорости и информационной прозрачности всех экономических процессов существующих организаций;

4. увеличение значимости аутсорсинга;

5. расширение интеллектуального предпринимательства.

К интеллектуальному предпринимательству обычно относят организации сферы образования; предприятия, занимающиеся производством инфопродукта, a также его хранением, переработкой и использованием; компании, занимающиеся предоставлением консалтинговых услуг [1]. 
Все возрастающую ценность в современной экономике, приобретают консалтинговые фирмы, которые с каждым днем все больше влияют на ценность «знаниевых» ресурсов экономики Российской Федерации. К «знаниевым» ресурсам обычно относят человеческий капитал, который включает в себя образование и качество обучения. В современных условиях, в целях увеличения производительности, повышения качества «новой рабочей силы», государство активно развивает «политику инвестиций в человеческий капитал», то есть практику вложений в человека, которые приносят продолжительный экономический эффект. Одним из наиболее популярных видов такого рода инвестиций являются «расходы на образование», которые включают в себя затраты на такой вид услуг, как образовательный консалтинг.

Образовательный консалтинг (ОК) представляет собой вид предпринимательской деятельности, сформированный на стыке сферы образования и консалтинга. Основной целью ОК является развитие интеллектуальных возможностей индивида за счет его собственных резервов. Каждый гражданин, с учетом своих возможностей, формирует «знаниевый» («интеллектуальный») капитал государства, от которого зависит уровень экономического развития страны.

Образовательный консалтинг по отношению к спросу, формируемому клиентами, подразделяется на процессный, экспертный, обучающий и внедренческий [2]. Все эти виды консалтинга в сфере образования направлены на развитие «интеллектуального капитала» страны, который, в свою очередь, является ведущим экономическим ресурсом «новой экономики». Исходя из этого, можно сделать вывод, что уровень экономического развития страны тесно связан с развитием консалтингового сектора экономики.

На основе работы Калюжновой Н.Я., Мрочковского Н.С можно выделить следующие роли образовательного консалтинга на фоне особенностей современной «знаниевой» экономики [1, С. 166-167; 3]: 
1. образовательный консалтинг, является одним из институтов рыночной экономики;

2. образовательный консалтинг формирует и/или развивает, повышает качество «интеллектуальных» ресурсов страны;

3. образовательный консалтинг помогает в разработке, реализации образовательных проектов;

4. образовательный консалтинг оказывает помощь образовательным организациям в повышении качества оказываемых образовательных услуг, а также помощь в адаптации к государственным программам;

5. образовательный консалтинг как инструмент повышения качества «интеллектуального капитала страны».

6. образовательный консалтинг нивелирует «интеллектуальный голод» среди молодежи.

Изменение характера современной экономики, модернизация российского образования, определили черты образовательного консалтинга, а именно:

1. принадлежность к сфере услуг;

2. науко-, интеллектуало- и знаниемкость;

3. междисциплинарность;

4. инновационность, мобильность;

5. объективность и субъективность образовательных консалтинговых услуг;

6. сложность потребительского выбора;

7. неотделимость образовательных консалтинговых услуг от консультанта и клиента, в т.ч. вовлеченность клиента в процесс производства консалтинговой услуги;

8. сложность оценки качества;

9. коммуникативность;

10. креативность, творческий характер. 
На основании вышеизложенного, мы видим, что основой «консалтингового» сектора «новой экономики России» являются: «интеллектуальный потенциал индивида», включающий в себя «знания»; «науко-», «интеллектуало-» и «знаниемкость», с учетом творческого компонента.

C точки зрения консалтинговой компании, осуществляющей свою деятельность в таком секторе экономики РФ, как - образование, и теории маркетинга, продуктом образовательных консалтинговых организаций, является образовательная консультационная услуга (консультации; тренинги; помощь в разработке, подготовке и реализации проектов и т.д.), реализуемая посредством программ, планов, которые разрабатывается на основе методических рекомендаций педагогов, консультантов, привлеченных со стороны экспертов для удовлетворения «образовательных» потребностей клиентов.

В заключение необходимо отметить, что в современных условиях экономического развития мировые державы большое внимание уделяют развитию «интеллектуальной» («зниниевой») составляющей ресурсов экономики страны. Данная тенденция вызывает рост значимости ОК одновременно со все возрастающей ролью человеческого капитала государства. В дальнейшем ОК, благодаря своим возможностям, может обеспечивать экономическую стабильность страны. В РФ, несмотря на возрастающую роль и значение консалтинга, состояние сферы ОК не в полной мере отвечает требованиям построения «знаниевой экономики» («новой», «экономики XXI века»), что, в свою очередь, не позволяет использовать все возможности ОК для повышения качества «знаниевых» ресурсов страны. 


\section{Литература:}

1. Калюжнова Н.Я. Роль консалтинга в развитии малого и среднего предпринимательства / Н.Я. Калюжнова, Н.С. Мрочковский // Вестник ИрГТУ . - 2013. - №7 (78). - С 164-173;

2. Лапекина, Н.Н. Роль и значение сферы образовательных услуг на современном этапе развития государства / Н.Н. Лапекина // Проблемы и перспективы развития образования в России. - 2011. - №8. - С. 344-348;

3. Мрочковский, Н.С. Институт консалтинга и его развитие в российской экономике [Электронный ресурс] / Н.С. Мрочковский // Современные проблемы науки и образования (электронный научный журнал). - 2013. № $6 . \quad$ - 6 Режим доступа: http://www.scienceeducation.ru/ru/article/view?id=11119 (дата обращения: 02.03.2016). 